\title{
RINGTAIL (BASSARISCUS ASTUTUS) ECOLOGY AND BEHAVIOR IN CENTRAL NEW MEXICO, USA
}

\author{
Robert L. Harrison ${ }^{1}$
}

\begin{abstract}
I studied the ecology and behavior of ringtails (Bassariscus astutus) in juniper (Juniperus monosperma) woodland on the Sevilleta National Wildlife Refuge in central New Mexico. Average home-range sizes of ringtails (males 462 ha, females 94 ha, $95 \%$ fixed kernel) were among the largest reported to date. Females moved least in summer and most in autumn, but males showed no seasonal trend in movements. The average stay in a single den was 1.3 days. I found no effect of the closeness of approach of the den observer on the distance moved between successive dens. Ringtails used a variety of den settings: rocks, trees, shrubs, rocks and shrubs, and holes in the ground. Males used trees and rocks more and shrubs less than females. In summer and autumn, ringtails used rocks more and shrubs less than expected, and in winter ringtails used rocks less and shrubs and holes in the ground more than expected. There was no tendency to reuse certain types of dens, and $31.6 \%$ of dens were reoccupied at least once. Most ringtails died before the age of 4 due to predation, resulting in an annual survival rate of 0.375 . Contrary to the popular conception that ringtails require open, permanent water for survival, 16 of 18 ringtail home ranges had no water source within them, and no ringtail was observed in the vicinity of water. Latrines of $\geq 2$ scats contained $89.4 \%$ of scats found. As measured by frequency of occurrence in scats, ringtails consumed primarily fruits, followed by arthropods, mammals, birds, and reptiles. Many arthropod prey were venomous or chemically defended. Average weights were $1.0 \mathrm{~kg}$ for males and $0.9 \mathrm{~kg}$ for females.
\end{abstract}

Resumen.-Estudié la ecología y el comportamiento de los cacomixtles (Bassariscus astutus) en el bosque de Juniperus monosperma, en el Refugio Nacional para la Vida Silvestre de Sevilleta en el centro de Nuevo México. El tamaño promedio del ámbito hogareño de los cacomixtles (machos: 462 ha, hembras: 94 ha y núcleo fijo del 95\%) se encuentra entre los más grandes que se han reportado hasta la fecha. Observé que las hembras se movieron menos en verano y más en otoño, pero los machos no demostraron una tendencia estacional en sus movimientos. El promedio de permanencia en una sola guarida fue de 1.3 días. No encontré ningún efecto de la proximidad del observador de guaridas sobre la distancia desplazada entre guaridas sucesivas. Los cacomixtles utilizaban una variedad de entornos para sus guaridas: rocas, árboles, arbustos, rocas y arbustos y huecos en el suelo. Los machos utilizaron más árboles y rocas y menos arbustos que las hembras. En verano y otoño, los cacomixtles utilizaron más rocas y menos arbustos que lo esperado y en invierno utilizaron menos rocas y más arbustos y huecos en el suelo que lo esperado. No hubo una tendencia a reutilizar ciertos tipos de guaridas, y un 31.6\% de las guaridas se volvieron a ocupar al menos una vez. La mayoría de los cacomixtles murieron antes de los cuatro años de edad debido a la depredación, lo que dio como resultado una tasa de supervivencia anual del 0.375. Contrario a la concepción popular de que los cacomixtles necesitan agua permanente para su supervivencia, 16 de los 18 ámbitos hogareños de los cacomixtles no tenían fuente de agua, y no se observó ningún cacomixtle en las cercanías de agua. Las letrinas de $\geq 2$ excrementos contenían el $89.4 \%$ de los excrementos encontrados. Según se midió por la frecuencia de ocurrencia en los excrementos, los cacomixtles consumieron principalmente frutas, seguidas de artrópodos, mamíferos, aves y reptiles. Muchas presas de artrópodos fueron venenosas o con defensas químicas. Los pesos promedios fueron de $1.0 \mathrm{~kg}$ para los machos y $0.9 \mathrm{~kg}$ para las hembras.

Ringtails (Bassariscus astutus) are the smallest members of the raccoon family, Procyonidae. Their distribution extends from Oregon, Nevada, Utah, Colorado, and Kansas through the southwestern states to southern Mexico (Fig. 1; Gehrt 2003). In general, ringtails are understudied, and little is known of their natural history in many areas, including New Mexico. They are believed to be habitat generalists and opportunistic omnivores (Gehrt
2003). Ringtails are strictly nocturnal and utilize dens daily. Home-range size estimates vary by a factor of over 60 , from 9 ha (Morales 2006) to 560 ha (Ackerson and Harveson 2006). The legal status of ringtails varies across their range. For example, ringtails are fully protected in California (California Department of Fish and Game 2012), but they may be killed at any time without limit in Texas (Texas Parks and Wildlife 2009). In New Mexico, ringtails

1Department of Biology, University of New Mexico, Albuquerque, NM 87131. E-mail: rharison@unm.edu 


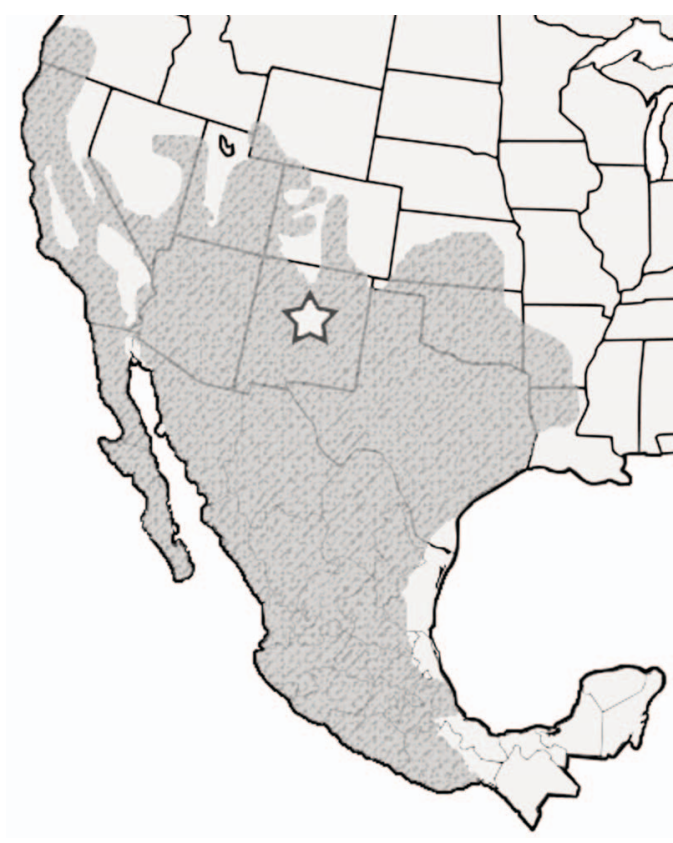

Fig. 1. Range of Bassariscus astutus (dark gray shading) and location of Sevilleta National Wildlife Refuge (star), New Mexico.

are protected furbearers and can be legally killed without limit during the trapping season of 1 November to 15 March (New Mexico Department of Game and Fish 2011). In years of high prices, over 100,000 ringtail pelts have been sold nationwide (Kaufman 1987). In New Mexico, an average of 546 ringtails were killed by trappers each year between 1980 and 2011, with as many as 1580 killed in a single season (New Mexico Department of Game and Fish, unpublished records). Given the lack of knowledge of ringtail ecology and the potential for high human-caused mortality, it is important that greater understanding of ringtail ecological relationships and population dynamics be obtained, especially in those areas where ringtails are not protected.

\section{STUDy AREA}

The study was conducted in the Los Pinos Range of the Sevilleta National Wildlife Refuge (NWR) and adjacent U.S. Department of Agriculture Bureau of Land Management lands, Socorro County, New Mexico (Fig. 1). Habitat was primarily juniper (Juniperus monosperma) savanna, with limited piñon-juniper (Pinus edulis, J. monosperma) woodland (described by Dick-Peddie 1993; see also http://sev.lter net.edu, research sites Goat Draw and Cerrom Montoso). Dominant grasses were grama grasses, including Bouteloua eriopoda, B. gracilis, B. curtipendula and B. hirsuta. Dominant shrubs were mountain mahogany (Cercocarpus montanus), scrub live oak (Quercus turbinella), gray oak (Q. grisea), and Apache plume (Fallugia paradoxa). Cacti purple-fruited prickly pear (Opuntia phaeacantha) and candelabra cholla $(O$. imbricata) were common. Elevations were 1900-2300 m. Topography was hilly, and generally very rocky, with many cliffs, outcroppings, talus slopes, and gravel fields. Mean monthly maximum and minimum temperatures were $20.5^{\circ} \mathrm{C}$ and $6.6^{\circ} \mathrm{C}$, respectively, from 1999 to 2007 , and $20.3^{\circ} \mathrm{C}$ and $6.6{ }^{\circ} \mathrm{C}$, respectively, in 2009 , the only year during fieldwork for which complete local weather data was available (Sevilleta LTER 2012). Annual precipitation averaged $284 \mathrm{~mm}$ from 1999 to 2007 and was $334 \mathrm{~mm}$ in 2009. There were only 3 sources of permanent water within the study area: 2 small water troughs for wildlife and a small pond for livestock outside of the refuge.

\section{Methods}

Trapping was conducted from September 2008 to April 2010. Ringtail tracking was conducted from September 2008 to April 2011. Ringtails were captured in $82 \times 26 \times 32 \mathrm{~cm}^{3}$ or $49 \times 17 \times 17 \mathrm{~cm}^{3}$ single-door cage traps (Tomahawk Live Traps, Tomahawk, WI) baited with canned sardines or with raisins and grape jelly. Bobcat (Lynx rufus) urine (Blackie's Blend, Glenmont, $\mathrm{OH}$ ) was used as a lure at one-half of the traps (Box 2002). I alternated combinations of baits and the lure to test effectiveness. I compared trapping success between baits with chi-square tests. I placed traps in rocky areas or dry creek beds where I found ringtail scats. Ringtails were transferred to a $32 \times 37 \times 77 \mathrm{~cm}^{3}$ restraint cage (Tomahawk Live Traps, Tomahawk, WI) for sedation by an intramuscular injection of $10 \mathrm{mg}$ Telazol ${ }^{\circledR}$ (Tiletamine $\mathrm{HCl}$ and Zolazepam $\mathrm{HCl}$, Fort Dodge Animal Health, Fort Dodge, IA) per kilogram of body weight. Ringtails were sexed, weighed, and measured; examined for injury, parasites, and pregnancy; and then fitted with a 20-g VHF radio-collar (Model 1565, Advanced Telemetry Systems, Isanti, MN) equipped with an 8-h mortality sensor. I compared body 
measurements between males and females with Student's $t$ tests. After completion of procedures, ringtails were returned to the trap, held until fully recovered, and then released at the capture site. Trapping and handling procedures were reviewed by Dr. Michael Richard, DVM, Albuquerque Biological Park, Albuquerque, New Mexico, and approved by the New Mexico Department of Game and Fish and the University of New Mexico Institutional Animal Care and Use Committee (Protocol No. 07UNM098-TR-100517-MCC).

Ringtails were located by radiotelemetry during weekly visits to the study area. To triangulate ringtail positions, I used 2-4 directions obtained no more than 20 minutes apart with a handheld $\mathrm{H}$-antenna by driving or hiking between telemetry sites. Maximum and minimum useful separations of ringtail directions were $160^{\circ}$ and $20^{\circ}$, respectively. I attempted to locate each ringtail once during daytime and 2-3 times during nighttime, with all relocations of a single individual at least 2 hours apart. I used the program Locate II (Nams 2000) to determine triangulated ringtail locations. I used the program Ranges 8 (Kenward et al. 2008) to estimate home-range sizes, using minimum convex polygon and fixedkernel methods. I compared home-range size estimates between males and females using Mann-Whitney $U$ tests, and using a Pearson correlation, I examined the relationship between number of relocation points and estimated home-range size. Nightly ringtail movements were measured by the distance moved between dens on successive days. I compared the movements of males and females with $t$ tests and compared movements by each sex between seasons with ANOVA procedures in Microsoft Excel ${ }^{\circledR}$.

Telemetry error was assessed by recording directions to radio-collared ringtails in dens, locating the dens by homing in on the signal afterward, then comparing the triangulated location with the true location. In this way, a sample $(n=30)$ of comparisons were obtained using ringtails in natural locations, rather than using radio-collars artificially placed in the study area. The average separation between direction recording sites was $0.58 \mathrm{~km}$. The average $95 \%$ error polygon (White and Garrott 1990:53) was $0.21 \mathrm{~km}^{2}$ for 2 directions obtained at $90^{\circ}$ to each other and from sites separated by $0.58 \mathrm{~km}$.
Previous authors have reported that ringtails change dens frequently (Toweill and Teer 1980, Callas 1987, Ackerson and Harveson 2006). It is conceivable that inspection by observers may have prompted ringtails to change dens sooner than they would have naturally. To examine the hypothesis that visitation by an observer at a den prompts ringtails to change dens, I used a $t$ test to compare the average distance between successively used dens when I approached no closer than $20 \mathrm{~m}(n=53$ dens) with the average distance between successively used dens when I approached within $1 \mathrm{~m}(n=66$ dens $)$. I alternated approaching dens within $1 \mathrm{~m}$ and not approaching within $20 \mathrm{~m}$ on a biweekly basis to avoid possible seasonal effects.

Ringtail activity level was measured by the number of variations of signal strength during 1-2 min observing sessions. I considered ringtails to be active if signal strength varied at least twice during a session and inactive otherwise. I qualitatively compared times of onset and cessation of ringtail activity to times of sunset and sunrise (UNSO, Astronomical Applications Department 2010).

I located dens by homing in on signals during daytime. I described den settings as in or behind rocks, shrubs, rocks and shrubs, trees, or holes in the ground. I also noted the presence or absence of woodrat (Neotoma sp.) middens because they provide additional structure to the microhabitats of dens. Seasons were autumn (September-November), winter (December-February), spring (March-May), and summer (June-August). I examined use of den settings with chi-square tests.

Causes of mortality of radio-collared ringtails were determined by examination in the field or by necropsy by Dr. Flint Taylor (Veterinary Diagnostic Services, New Mexico Department of Agriculture) or Dr. John Heidrich (Town and Country Animal Clinic, Albuquerque, NM). Survival rates were estimated using a Kaplan-Meier estimator with a staggeredentry design (Pollock et al. 1989). Dead ringtails were deposited at the Museum of Southwestern Biology, University of New Mexico, Albuquerque, New Mexico. Ages of dead ringtails were determined by cementum analysis of a lower canine tooth by Matson's Laboratory, Milltown, Montana.

I collected ringtail scats during periodic surveys of known areas of ringtail activity and 
haphazardly when encountered. I defined latrines as accumulations of $\geq 2$ scats. I measured the maximum diameter of scats to the nearest millimeter to aid in future identification of ringtail scats (Halfpenny 1986). Species origin of scats was confirmed by mitochondrial DNA analysis by Dr. David Paetkau, Wildlife Genetics International, Nelson, British Columbia, Canada. Initial diet assessment was performed by ATCG Laboratory (Central Michigan University, Mt. Pleasant, MI, Dr. Bradley Swanson, Director). Scats were dissected without washing. Initial identification of contents was obtained by comparison to museum specimens, seeds collected from the study area, and published references, with consultation by experts at Central Michigan University. I performed further identification of seeds and teeth. Identification of insect remains was confirmed and expanded by Dr. Sandra Brantley, Arthropod Division, Museum of Southwestern Biology, University of New Mexico, Albuquerque, New Mexico. I described diet by percent frequency of occurrence of prey items in scats (percentage of scats in which a prey item appeared) and percent frequency of occurrence in all prey items (percentage of all prey items represented by a specific prey item; Lancia et al. 2005). Species identification of hair found in scats but not accompanied by identifiable teeth or bones was conducted using mitochondrial DNA by Dr. David Paetkau, Wildlife Genetics International, Nelson, British Columbia, Canada. All hairs were cleaned vigorously in hot water prior to DNA extraction. Because ringtail DNA tended to be more abundant in extracts than DNA from prey species, a primer system was designed that amplified poorly from procyonids, allowing prey DNA to out-compete ringtail DNA during PCR. DNA was extracted by first dissolving 40-80 hair shafts in a mixture of QIAGEN ATL lysis buffer, proteinase $\mathrm{K}$, and dithiolthreitol (DTT; Müller et al. 2007, Sato et al. 2010). Once the hair shafts were fully dissolved, DNA was purified using QIAGEN DNeasy Tissue kits. Deviations from QIAGEN's standard protocol were as follows: (1) adding DTT to the initial ATL digest; (2) extending the length of that digest from $1 \mathrm{~h}$ to overnight; and (3) recovering the DNA in a volume of $30 \mu \mathrm{L}$ instead of the more typical 200-400 $\mu \mathrm{L}$ suggested by QIAGEN1. The species test was a sequence-based analysis of the mitochondrial 16S rRNA gene (Johnson and O'Brien 1997). A dramatic reduction in amplification of ringtail DNA was achieved by designing a "universal" mammalian 16S primer ending at a position where ringtails have a different nucleotide than rodents and lagomorphs. Two variants were observed in rodents, necessitating the use of 2 anti-ringtail primers which were mixed in equal proportions prior to use.

\section{RESULTS}

I captured and radio-collared 18 ringtails (9 M, 9 F) in 523 trap-nights, achieving success rates of $3.4 \%$ for initial captures and $8.4 \%$ for both initial captures and recaptures. I also captured rock squirrels (Spermophilus variegatus; 16), gray foxes (Urocyon cinereoargenteus; 13), woodrats (Neotoma sp.; 6), and one hog-nosed skunk (Conepatus mesoleucus). Considering initial captures only, I found no effect of bait combinations (canned fish, canned fish plus bobcat urine, raisins and grape jelly, raisins and grape jelly and bobcat urine) on trapping success rate $\left(\chi^{2}=0.524, \mathrm{v}=3, P=\right.$ 0.919). I also found no effect of using bobcat urine on trapping success rate $\left(\chi^{2}=0.845, \mathrm{v}\right.$ $=1, P=0.845)$. Considering initial captures and recaptures, I found no effect of bait combinations on trapping success rates for all ringtails $\left(\chi^{2}=2.364, \mathrm{v}=3, P=0.501\right)$, females only $\left(\chi^{2}=0.977, \mathrm{v}=3, P=0.200\right)$, or males only $\left(\chi^{2}=2.586, \mathrm{v}=3, P=0.452\right)$. I also found no effect of using bobcat urine on trapping success rates for all ringtails $\left(\chi^{2}=0.818\right.$, $\mathrm{v}=1, P=0.243)$, females only $\left(\chi^{2}=0.067, \mathrm{v}\right.$ $=1, P=0.813)$, or males only $\left(\chi^{2}=0.862, \mathrm{v}\right.$ $=1, P=0.383)$. Males were not more likely than females to be recaptured $\left(\chi^{2}=0.136, \mathrm{v}\right.$ $=1, P=0.726$ ).

All ringtails were adult size when captured ( $\geq 0.75$ kg; Kaufman 1987). In comparisons of weight and body size of males and females, males were significantly longer in their bodies, but they were not significantly heavier or longer in foot, tail, or ear length (Table 1). The 95\% confidence interval for the difference of body length between males and females was $16 \pm 4.9 \mathrm{~mm}$. Tail length as a percentage of body length was not significantly different between males and females $(t=0.662, \mathrm{df}=15$, $P=0.518)$. No females were obviously pregnant when weighed. Captures of males and 
TABLE 1. Mean (SD) weight and body size measurements of ringtails on the Sevilleta National Wildlife Refuge, New Mexico, 2008-2011.

\begin{tabular}{|c|c|c|c|c|}
\hline & Males $(n=9)$ & Females $(n=9)$ & $\mathrm{M}: \mathrm{F}$ & $P^{\mathrm{a}}$ \\
\hline Weight (kg) & $1.0(0.1)$ & $0.9(0.1)$ & 1.10 & 0.053 \\
\hline Body length ${ }^{b}(\mathrm{~mm})$ & $394(15)$ & $378(15)$ & 1.04 & 0.037 \\
\hline Tail length (mm) & $375(21)$ & $367(17)$ & 1.02 & 0.417 \\
\hline Ear length (mm) & $48(3)$ & $47(3)$ & 1.04 & 0.185 \\
\hline Hind foot length (mm) & $66(3)$ & $63(2)$ & 1.04 & 0.062 \\
\hline
\end{tabular}

2-tailed $t$ test, $\mathrm{df}=16$

bSnout to base of tail

TABLE 2. Average home-range sizes (ha) of ringtails during inactive periods (in dens), active periods (out of dens), and inactive and active periods combined on the Sevilleta National Wildlife Refuge, New Mexico, 2008-2011.

\begin{tabular}{|c|c|c|c|c|}
\hline & & Inactive & Active & Inactive and active \\
\hline \multicolumn{5}{|l|}{ Males } \\
\hline \multirow[t]{2}{*}{ Fixed kernel } & $95 \%$ & 441 & 543 & 462 \\
\hline & $50 \%$ & 138 & 175 & 149 \\
\hline \multirow[t]{3}{*}{ Minimum convex polygon } & $100 \%$ & 755 & 949 & 806 \\
\hline & $95 \%$ & 476 & 438 & 528 \\
\hline & $50 \%$ & 85 & 133 & 105 \\
\hline$n$ & & 6 & 2 & 6 \\
\hline \multicolumn{5}{|l|}{ Females } \\
\hline \multirow[t]{2}{*}{ Fixed kernel } & $95 \%$ & 76 & 142 & 94 \\
\hline & $50 \%$ & 22 & 47 & 27 \\
\hline \multirow[t]{3}{*}{ Minimum convex polygon } & $100 \%$ & 129 & 190 & 152 \\
\hline & $95 \%$ & 93 & 161 & 115 \\
\hline & $50 \%$ & 19 & 38 & 28 \\
\hline$n$ & & 7 & 3 & 7 \\
\hline
\end{tabular}

females were similarly distributed throughout the year (January-April: 8 M, 7 F; September-November: $3 \mathrm{M}, 4 \mathrm{~F}$; one male and one female were each recaptured and reweighed twice).

Home-range size estimates were available for 13 ringtails (7 F, 6 M; Table 2). Ringtails were observed for an average of 237 days (range 62-602 days), yielding an average of 70 relocations each (range 21-199 points). Due to the rugged terrain of the study area and lack of road access, some ringtails could be observed only during daytime when it was possible to hike to observation points such as hilltops, and other ringtails could be observed only during nighttime when they were outside of dens and their signals could be obtained from the road system. No home-range size estimate was recorded until the observed home-range size appeared to reach a plateau with successive additions to the set of observations. Home-range size estimates for inactive periods were much larger for males than females $n_{1}=6, n_{2}=7$, $U \geq 36, P \leq 0.05$ for all 5 home-range size estimators in Table 2). The sample during active periods was too small for statistical comparison.
Home-range size estimates for ringtails with both inactive (in dens) and active (out of dens) estimates were available for 5 ringtails ( $3 \mathrm{~F}, 2$ M). Average home-range size calculated from inactive estimates were as follows: $95 \%$ fixed kernel, 239 ha; $50 \%$ fixed kernel, 69 ha; 100\% minimum convex polygon (MCP), 572 ha; $95 \%$ MCP, 302 ha; 50\% MCP, 53 ha. Average homerange size calculated from active estimates were as follows: $95 \%$ fixed kernel, 302 ha; $50 \%$ fixed kernel, 98 ha; 100\% MCP, 494 ha; $95 \%$ MCP, 272 ha; 50\% MCP, 76 ha. Sample size was too small for statistical analysis, but kernel and 50\% MCP estimates may have been larger for active periods than for inactive periods. In contrast, $100 \%$ and $95 \%$ MCP estimates may have been larger for inactive periods than active periods. I found no significant correlation between the number of relocation points and home-range size $\left(R^{2}=0.122, F=1.114\right.$, $P=0.322, n=10$ ringtails $)$.

On an annual basis, males did not move significantly farther between dens than females $(t=0.292$, df $=170, P=0.770)$, and there were no there seasonal differences in male movements $(F=0.736, \mathrm{df}=52, P=$ 
TABLE 3. Differences in den-to-den movements $(\mathrm{m})$ between successive days by ringtails $\left(n_{\delta^{*}}=4, n_{\uparrow}=6\right)$ on the Sevilleta National Wildlife Refuge, New Mexico, 2008-2011.

\begin{tabular}{|c|c|c|c|c|c|c|c|}
\hline & $n$ & Mean & SD & Minimum & Maximum & Median & $P$ \\
\hline \multicolumn{8}{|l|}{ Annual } \\
\hline Males & 53 & 574 & 620 & 0 & 2767 & 372 & \multirow[t]{3}{*}{0.770} \\
\hline Females & 119 & 542 & 689 & 0 & 3046 & 236 & \\
\hline All ringtails & 172 & 552 & 667 & 0 & 3046 & 278 & \\
\hline \multicolumn{8}{|l|}{ Winter } \\
\hline Males & 12 & 501 & 546 & 0 & 1263 & 319 & \multirow[t]{2}{*}{0.719} \\
\hline Females & 37 & 437 & 525 & 0 & 2007 & 158 & \\
\hline \multicolumn{8}{|l|}{ Spring } \\
\hline Males & 22 & 714 & 616 & 0 & 2400 & 575 & \multirow[t]{2}{*}{0.640} \\
\hline Females & 35 & 638 & 575 & 0 & 2480 & 577 & \\
\hline \multicolumn{8}{|l|}{ Summer } \\
\hline Males & 10 & 385 & 849 & 0 & 2767 & 72 & \multirow[t]{2}{*}{0.340} \\
\hline Females & 22 & 112 & 178 & 0 & 776 & 28 & \\
\hline \multicolumn{8}{|l|}{ Autumn } \\
\hline Males & 9 & 540 & 416 & 71 & 1261 & 520 & \multirow[t]{2}{*}{0.118} \\
\hline Females & 25 & 939 & 1030 & 0 & 3046 & 590 & \\
\hline \multicolumn{8}{|c|}{ Seasonal—all ringtails } \\
\hline Winter & 49 & 453 & 525 & 0 & 2007 & 158 & \multirow[t]{4}{*}{$<0.001$} \\
\hline Spring & 57 & 667 & 587 & 0 & 2480 & 577 & \\
\hline Summer & 32 & 197 & 497 & 0 & 2767 & 37 & \\
\hline Autumn & 34 & 883 & 920 & 0 & 3046 & 555 & \\
\hline \multicolumn{8}{|l|}{ Observer } \\
\hline$<1 \mathrm{~m}$ & 66 & 584 & 762 & 0 & 3046 & 184 & \multirow[t]{2}{*}{0.184} \\
\hline$>20 \mathrm{~m}$ & 53 & 410 & 621 & 0 & 2505 & 71 & \\
\hline
\end{tabular}

0.535; Table 3). Female movements were least in summer, and greatest in autumn $(F=$ 7.091, df $=118, P<0.001$; Table 3). Because of large variation, seasonal movements did not show significant differences between sexes (Table 3). Both males and females remained in the same den on $24.4 \%$ of successive nights, thus changing dens approximately 3 of 4 nights. Average stay in a given den was 1.3 days.

Although ringtails appeared to move greater distances between dens on successive nights when I approached within $1 \mathrm{~m}$ of dens than on successive nights when I stayed at least $20 \mathrm{~m}$ away, differences were not significant due to large variations $(t=1.338, \mathrm{df}=117, P=$ 0.184; Table 3). Also, ringtails changed dens during $74.2 \%$ of nights after I approached within $1 \mathrm{~m}$ and during $73.6 \%$ of nights after I remained at least $20 \mathrm{~m}$ away.

Ringtails were completely nocturnal, with no significant activity between sunrise and sunset (Fig. 2). Activity increased to nighttime levels within the first hour after sunset and decreased to zero within the last hour before sunrise.

Overall, approximately $50 \%$ of dens were in rocks, $25 \%$ were in shrubs, and $25 \%$ were in shrubs and rocks, holes in the ground (primarily holes in dry creek banks), and trees (Table 4). Den type use varied by gender $\left(\chi^{2}=18.558\right.$, $\mathrm{v}=4, P<0.001)$. Males used trees more and rocks and shrubs less compared with females. Den settings containing woodrat middens were mostly associated with shrubs, as well as rocks to a lesser extent (Table 4). Males and females were not different in their use of dens with woodrat middens $\left(\chi^{2}=0.634, \mathrm{v}=2, P=\right.$ $0.732)$. The distribution of den settings did not differ between dens that were used only once and dens used more than once $\left(\chi^{2}=4.313\right.$, v $=4, P=0.382)$. Den setting use varied by season $\left(\chi^{2}=54.954, \mathrm{v}=12, P<0.001\right)$. In summer and autumn, ringtails used rocks more than expected and shrubs less than expected. In winter, ringtails used rocks less than expected and shrubs and holes in the ground more than expected. No preferences were found in spring.

Of 237 individual dens observed, $68.4 \%$ were used once, $18.6 \%$ were used twice, $12.2 \%$ were used 3-8 times, and $0.8 \%$ were used 9-10 times. No tendency was found for ringtails to reuse certain den settings more than others among those dens used from 1 to 4 days $\left(\chi^{2}=24.197, \mathrm{v}=24, P=0.706\right)$. Sample size was too small to include dens used more than 4 days. 


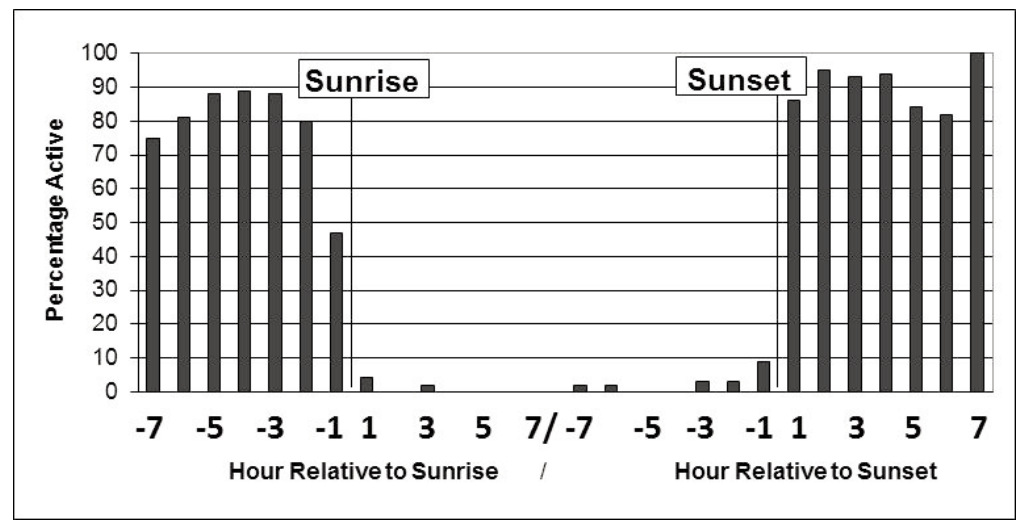

Fig. 2. Percentages of activity observations $(n=597)$ classified as active (out of dens) versus time relative to sunrise and sunset for ringtails on the Sevilleta National Wildlife Refuge, New Mexico, 2008-2011.

TABLE 4. Settings of dens used by ringtails ( 5 males and 7 females) on the Sevilleta National Wildlife Refuge, New Mexico, 2008-2011.

\begin{tabular}{lccc}
\hline Settings & Dens & Males & Females \\
\hline All den settings & & & \\
$n$ & 387 & 124 & 263 \\
Rocks & $52.5 \%$ & $54.8 \%$ & $51.3 \%$ \\
Shrubs & $25.5 \%$ & $21.0 \%$ & $27.8 \%$ \\
Rocks and shrubs & $11.1 \%$ & $6.5 \%$ & $13.3 \%$ \\
Trees & $5.7 \%$ & $12.1 \%$ & $2.7 \%$ \\
$\quad$ Holes in ground & $5.2 \%$ & $5.6 \%$ & $4.9 \%$ \\
Den settings containing & woodrat & (Neotoma sp.) & middens \\
$n$ & 71 & 20 & 51 \\
Rocks & $23.9 \%$ & $30.0 \%$ & $21.6 \%$ \\
Shrubs & $63.4 \%$ & $60.0 \%$ & $64.7 \%$ \\
Trees & $12.7 \%$ & $10.0 \%$ & $13.7 \%$ \\
\hline
\end{tabular}

Predation was the most common cause of death of radio-collared ringtails $(5 \mathrm{M}, 4 \mathrm{~F})$. In 6 of 9 cases, I found only fur or a few body parts remaining. In 2 cases, most of the bodies were intact, but meat had been neatly stripped down to bones, suggesting avian predation. I found remains of 6 of 9 ringtails that died of predation in open areas away from rocky cliffs or outcroppings. Although these ringtails may have been carried away from the site of capture, ringtails in open areas are more vulnerable to predation. Two additional ringtails were found intact with no traumatic injuries and cause of death unknown. One additional juvenile female died after being attacked while in a trap. Tracks in snow implicated that a cougar (Puma concolor) was responsible. The ringtail lost one front paw and had a severe laceration to an upper forelimb.
She was treated by John Heidrich, DVM, but died within $24 \mathrm{~h}$ of release. The signals of 4 males vanished abruptly after they presumably left the study area. Premature transmitter failure cannot be ruled out. The signal of one female, who had been monitored in the same area for over a year, was also lost abruptly, suggesting transmitter failure.

Annual survival averaged over 2 years was 0.367 for males (95\% CI limits: $0.000,0.770 ; n$ $=9$ ), 0.384 for females (95\% CI limits: 0.114, $0.718 ; n=9$ ), and 0.375 for males and females combined (95\% CI limits: 0.102, 0.649; $n=$ 18). Ages at death as determined by cementum analysis were available for 9 ringtails: $<1$ year, 1 female; $1-2$ years, 4 females; $2-3$ years, 1 female, 2 males; 4-5 years, 1 male.

Mitochondrial DNA analysis was used to identify the species of origin for the first 146 scats collected. Of these, $93.2 \%$ were confirmed as ringtail. The remainder failed or contained mixed results. No scats were identified as species other than ringtail, so DNA confirmation was not conducted for the remainder of scats used for the diet sample. The average maximum diameter $( \pm 1$ SD) for 75 confirmed ringtail scats was $10.5 \pm 2.5 \mathrm{~mm}$ (range 4-14 $\mathrm{mm})$. I collected scats from 98 deposition sites, of which $59.2 \%$ were latrines containing $\geq 2$ scats. Latrines contained $89.4 \%$ of observed scats ( $n \geq 378$ observed scats). Latrines of $2-7$ scats contained $45.7 \%$ of scats, and latrines of $\geq 8$ scats contained $43.7 \%$ of scats. It was often difficult to count exactly the number of scats in a latrine because of disintegration of older scats. The average $( \pm 1$ SD) number of scats found in 
latrines was $5.8 \pm 3.5$. The maximum number of scats found in a single latrine was $\geq 20$.

DNA analysis of prey hair in scats was successful for 32 of 37 hair samples submitted. Scats most commonly contained remains of plants, followed by arthropods, mammals, birds, and reptiles (Table 5). Among the individual diet items found, arthropods were the most common, followed by plants, mammals, birds, and reptiles (Table 5).

TABLE 5. Diet of ringtails on the Sevilleta National Wildlife Refuge, New Mexico, 2008-2011, based on 314 scats and 1066 individual prey items found in scats. For arthropods, cd = chemically defended, $\mathrm{v}=$ venomous. For mammals, DNA = hair identified by DNA analysis.

\begin{tabular}{|c|c|c|}
\hline & $\%$ of scats & $\%$ of prey items \\
\hline Plants & 82.5 & 33.6 \\
\hline Juniperus monosperma & 40.1 & 11.8 \\
\hline Opuntia phaeacantha & 26.8 & 7.9 \\
\hline Quercus sp. & 1.3 & 0.4 \\
\hline Pinus edulis & 36.0 & 10.6 \\
\hline Prosopis glandulosa & 1.9 & 0.6 \\
\hline Unidentified plant ( $>3$ species) & 8.0 & 2.3 \\
\hline Birds & 26.1 & 7.7 \\
\hline Campylorhynchus brunneicapillus & 1.3 & 0.4 \\
\hline Colaptes auratus & 1.6 & 0.5 \\
\hline Junco hyemalis & 0.3 & 0.1 \\
\hline Unidentified bird & 22.9 & 6.8 \\
\hline Mammals & 40.4 & 12.3 \\
\hline Spermophilus variegatus (DNA) & 0.3 & 0.1 \\
\hline Heteromyidae & 3.2 & 0.9 \\
\hline Dipodomys ordii (DNA) & 0.6 & 0.2 \\
\hline Perognathus sp. & 1.9 & 0.6 \\
\hline Perognathus flavus (DNA) & 0.3 & 0.1 \\
\hline Chaetodipus sp. & 0.6 & 0.2 \\
\hline Reithrodontomys sp. & 1.3 & 0.4 \\
\hline Peromyscus sp. & 6.4 & 1.9 \\
\hline Peromyscus boylii (DNA) & 2.5 & 0.8 \\
\hline Peromyscus truei (DNA) & 1.3 & 0.4 \\
\hline Onychomys sp. & 1.9 & 0.6 \\
\hline Neotoma sp. (DNA) & 7.6 & 2.3 \\
\hline Neotoma albigula & 2.9 & 0.8 \\
\hline Neotoma mexicana & 1.0 & 0.3 \\
\hline Neotoma micropus (DNA) & 1.0 & 0.3 \\
\hline Unidentified mammal & 21.0 & 6.2 \\
\hline Reptiles & 2.2 & 0.7 \\
\hline Egg shell & 0.3 & 0.1 \\
\hline Bones & 0.3 & 0.1 \\
\hline Skin & 0.3 & 0.1 \\
\hline Scales & 1.3 & 0.4 \\
\hline Bone fragments (bird, mammal, or reptile) & 0.1 & 0.3 \\
\hline Arthopods & 48.1 & 45.5 \\
\hline Arachnida & 11.8 & 3.8 \\
\hline Araneae (v) & 3.5 & 1.1 \\
\hline Tibellus sp. (v) & 0.3 & 0.1 \\
\hline Latrodectus hesperus (v) & 2.2 & 0.7 \\
\hline Sclerosomatidae $(\mathrm{cd})$ & 1.3 & 0.4 \\
\hline Eremobates sp. & 1.6 & 0.5 \\
\hline Mastigoproctus giganteus (cd, v) & 6.4 & 1.9 \\
\hline Scolopendra sp. (v) & 13.4 & 3.9 \\
\hline Diplopoda $(\mathrm{cd})$ & 2.5 & 0.8 \\
\hline Insecta & 45.5 & 36.5 \\
\hline Coleoptera & 29.9 & 13.2 \\
\hline Carabidae & 15.9 & 5.0 \\
\hline Amara sp. & 2.2 & 0.7 \\
\hline Pasimachus sp. & 1.3 & 0.4 \\
\hline Curculionidae & 2.2 & 0.7 \\
\hline Ophryastes sp. & 0.3 & 0.1 \\
\hline
\end{tabular}


Table 5. Continued

\begin{tabular}{|c|c|c|}
\hline & $\%$ of scats & $\%$ of prey items \\
\hline Nitidulidae & 0.3 & 0.1 \\
\hline Scarabaeidae & 5.1 & 1.5 \\
\hline Ligyrus gibbosus & 0.6 & 0.2 \\
\hline Paracotalpa puncticollis & 0.3 & 0.1 \\
\hline Tenebrionidae & 15.0 & 4.4 \\
\hline Eleodes sp. (cd) & 14.0 & 4.1 \\
\hline Stenomorpha sp. & 1.0 & 0.3 \\
\hline Heteroptera & 7.6 & 2.3 \\
\hline Alydidae (cd) & 1.9 & 0.6 \\
\hline Alydus sp. (cd) & 0.3 & 0.1 \\
\hline Stachyocnemis apicalis (cd) & 1.3 & 0.4 \\
\hline Leptoglossus sp. (cd) & 0.3 & 0.1 \\
\hline Cydnidae $(\mathrm{cd})$ & 1.6 & 0.5 \\
\hline Pentatomidae $(\mathrm{cd})$ & 0.3 & 0.1 \\
\hline Cicadidae & 1.0 & 0.3 \\
\hline Hymenoptera (v) & 8.9 & 2.7 \\
\hline Formicidae (v) & 8.6 & 2.6 \\
\hline Camponotus sp. (v) & 0.3 & 0.1 \\
\hline Crematogaster sp. (v) & 2.2 & 0.7 \\
\hline Lepidoptera $(\mathrm{cd})$ & 2.9 & 0.8 \\
\hline Mantodea & 2.2 & 0.7 \\
\hline Orthoptera & 40.1 & 16.3 \\
\hline Acrididae & 29.9 & 8.9 \\
\hline Oedipodinae & 29.3 & 8.6 \\
\hline Gomphocerinae & 1.0 & 0.3 \\
\hline Gryllus sp. & 8.9 & 2.6 \\
\hline Rhaphidophoridae & 0.3 & 0.1 \\
\hline Brachystola magna $(\mathrm{cd})$ & 3.8 & 1.1 \\
\hline Stenopelmatus sp. & 7.6 & 2.3 \\
\hline Tettigoniidae & 1.6 & 0.5 \\
\hline Siphonaptera & 0.6 & 0.2 \\
\hline Unidentified arthropod & 1.6 & 0.5 \\
\hline
\end{tabular}

\section{Discussion}

Trapping success in this study was near the maximum of the range of successes previously reported (Belluomini 1983, Lacy 1983, Callas 1987, Yarchin 1988, Wyatt 1993, Ackerson and Harveson 2006, Morales 2006). A variety of baits and lures have been used previously, including strawberry and blackberry jams, raisins, muskrat (Ondatra zibethicus) meat, sardines, chicken, canned cat food, apples, tortillas, strawberry and raisin yogurt, and bobcat urine. However, no previous study quantified the efficiency of its baits. Neither bait type nor presence of a lure was found to affect capture success in this study. Given the omnivorous diet of ringtails, a variety of baits may be effective. Availability of natural foods may affect the attractiveness of baits, and I suggest that future researchers test several types.

Weights and body measurements of ringtails on the Sevilleta National Wildlife Refuge fell within ranges previously reported (Gehrt
2003). In general, ringtails in New Mexico appear to be of medium size, in agreement with a rangewide examination of skulls of museum specimens by Kortlucke (1984).

Average ringtail home-range size estimates from the Sevilleta NWR were among the largest reported, exceeded only by those of west Texas (Ackerson and Harveson 2006). Males had larger home ranges than females, as found in all previous studies. Because 4 of 6 radio-collared males apparently left the study area, they may have been transients with home ranges larger than those of residents. However, the largest observed male home range (95\% fixed kernel 732 ha, 100\% MCP $1771 \mathrm{ha}$ ) was that of the male ringtail observed the longest (303 days until he was killed) and thus the most likely to have been a resident.

Home-range size estimates in the ringtail literature have been based on a variety of lengths of time. I found no correlation between the number of relocation points and home-range size on the Sevilleta, indicating 
that my relocation sample sizes adequately estimated home-range sizes. Some previous home-range studies have used den locations only (Toweill 1976, Callas 1987), which raises the question of the relationship between homerange sizes based on dens only versus sizes based on nighttime observations only. No study previous to this one has made the comparison. I found that the relationship between the 2 measures may depend on the method of homerange estimation used. For minimum convex polygon estimators, how peripheral locations are excluded may also affect the relationship. Dens on the Sevilleta NWR were distributed widely throughout home ranges and not clustered. Similar observations were made by Trapp (1973), Toweill (1976), and Lacy (1983). It was not uncommon for dens to be located on the periphery of home ranges, which for some home ranges produced the unexpected result that estimates for active home-range sizes were smaller than home-range sizes based upon dens.

I found no significant effect of observer distance on distance moved between successive dens or on frequency of den changes, thus validating previous reports of den-changing frequency. Both this study and Yarchin (1994) found approximately one-third of dens to be reused during the observation period. Average distances between successive dens were farther on the Sevilleta NWR than distances reported previously from south central Texas (306 mToweill 1976) and west Texas (186 m-Ackerson and Harveson 2006), but they were shorter than reported from northwestern California (854 m-Callas 1987). These observations suggest that ringtails on the Sevilleta move about their home ranges more extensively than ringtails in Texas but less extensively than those in northwestern California. These movement patterns are most likely due to differences in resource availability.

Small sample size resulted in a large 95\% confidence interval for ringtail survival. However, ringtail survival appeared to be low, as would be expected for a small animal with a large number of potential predators. The only other reported survival estimate was that of Ackerson and Harveson (2006), which was $0.191 \pm 0.099$. I found no indication of a seasonal increase in mortality. In contrast, Ackerson and Harveson (2006) reported an increase in spring. Based on the distribution of ages of dead ringtails, adult ringtails average $1-3$ years old. Of 18 ringtails radio-collared, only one remained alive and in the study area 2 years after trapping began, although at least one and as many as 5 additional ringtails may have been in the area carrying dysfunctional radiocollars. Ringtail populations likely experience high turnover and are thus very dynamic.

Management programs that reduce the density of predators on ringtails would be beneficial to ringtail populations. Aerial gunning of coyotes (Canis latrans) would be beneficial, but such action is very controversial. Elimination of furbearer trapping might benefit ringtails, as ringtails are attracted to the same traps as larger animals, but may also ultimately be detrimental to ringtails because the density of predators such as gray foxes and bobcats would increase. Given the flexibility of ringtail diet and den site selection, habitat modifications to benefit ringtails beyond restoring degraded habitats do not appear to be useful. The relatively large home ranges observed in this study indicate that ringtail populations in New Mexico may not be as dense as in other states, and thus greater care should be exercised by wildlife managers to ensure that ringtail populations do not become depleted by trapping.

Only 2 of the observed ringtail home ranges in this study contained a permanent water source. Neither ringtail was ever observed in the vicinity of this resource, which was a livestock watering pond in a valley lined by small cliffs. It is often stated in summaries of ringtail ecology as recent as Gehrt (2003) that ringtails require open water or that they are rarely found far from water sources. This erroneous concept originated from Grinnell et al. (1937), who based their assertion on an unexamined statement from a single trapper. Both Richards (1976) and Chevalier (1984) presented evidence that ringtails can live without freestanding water if their diet is sufficient, which appears to be the case on the Sevilleta NWR. Toweill and Teer (1980) also reported ringtail home ranges with no permanent water. Open water is not an essential habitat requirement of ringtails.

The range of maximum scat diameters verified as ringtail in this study may be narrower than the true range. I did not collect scats $>14 \mathrm{~mm}$ in diameter to avoid collecting gray fox scats. I also did not collect scats $<4 \mathrm{~mm}$ to 
avoid collecting squirrel scats. Trapp (1973) reported an average $( \pm 1$ SD) scat length of $9.63 \pm 1.87 \mathrm{~mm}$ (range $1-13 \mathrm{~mm})$, but he identified scats by odor, appearance, and location. It seems unlikely that ringtail scats could be as small as $1 \mathrm{~mm}$ in diameter. The averages reported by Trapp (1973) and this study are likely close to the true averages, but the true range may be closer to $3-17 \mathrm{~mm}$.

Ringtails on the Sevilleta NWR were truly omnivorous. Considering the 4 primary diet categories (plants, arthropods, mammals, and birds), $28.8 \%$ of scats contained remains from one diet category, $45.0 \%$ contained 2 categories, $24.0 \%$ contained 3 categories, and $2.2 \%$ contained 4 categories. Among arthropod prey, remains of as many as 15 distinct taxa were found within a single scat. Many ringtail arthropod prey on the Sevilleta NWR were chemically defended or venomous (Table 5). For example, vinegaroons (Mastigoproctus giganteus) defend themselves with acetic and caprylic acids (Eisner 2003). How ringtails cope with such chemicals is not known. Conspicuously absent from items found in scats in this study were remains of acorn nuts from oak trees and shrubs (Quercus sp.). Acorns were commonly available in the Sevilleta NWR. Some diet studies have reported acorn consumption (Taylor 1954, Wood 1954), but others have not (Trapp 1973, Toweill and Teer 1980, Yarchin 1988, Ackerson and Harveson 2006, this study). Species of oak available may explain the difference.

\section{ACKNOWLEDGMENTS}

I thank the following colleagues for their valuable help in this study of ringtails: Jon Erz and Richard Pritchard of the Sevilleta National Wildlife Refuge provided logistical assistance and permission to conduct this study on the refuge; Drs. John Heidrich and Mike Richard provided assistance with ringtail handling procedures and emergency care of an injured ringtail; Dr. Sandra Brantley identified arthropod species; Dr. David Paetkau confirmed the species depositing scats; and Dr. Bradley Swanson and his staff conducted the initial processing of scat samples.

\section{Literature Cited}

ACKerson, B.K., And L.A. Harveson. 2006. Characteristics of a ringtail (Bassariscus astutus) population in
Trans Pecos, Texas. Texas Journal of Science 58: 169-184.

Belluomini, L.A. 1983. Ringtail (Bassariscus astutus) distribution and abundance in the Central Valley of California. Master's thesis, California State University, Sacramento, CA.

Box, B. 2002. Wrangling ringtails. Trapper and Predator Caller, April-May:40-41.

California Department of Fish and Game. 2012. Fully protected animals [online]. [Cited 31 January 2012]. Available from: http://www.dfg.ca.gov/wildlife/non game/t_e_spp/fully_pro.html

Callas, R. $\overline{1}$ - 87 . Ringtail (Bassariscus astutus) den and habitat use in northwestern California. Master's thesis, Humboldt State University, Arcata, CA.

Chevalier, C.D. 1984. Water requirements of free-ranging and captive ringtail cats (Bassariscus astutus) in the Sonoran Desert. Master's thesis, Arizona State University, Tempe, AZ.

Dick-Peddie, W.A. 1993. New Mexico vegetation, past, present, and future. University of New Mexico Press, Albuquerque, NM.

Eisner, T. 2003. For love of insects. Belknap Press of Harvard University Press, Cambridge, MA.

Genrt, S.D. 2003. Raccoons and allies. Pages 611-634 in G.A. Feldhamer, B.C. Thompson, and J.A. Chapman, editors, Wild mammals of North America. Johns Hopkins University Press, Baltimore, MD, and London, United Kingdom.

Grinnell, J., J.S. Dixon, and J.M. Linsdale. 1937. Furbearing mammals of California. Volume I. University of California Press, Berkeley, CA.

Halfpenny, J. 1986. A field guide to mammal tracking in western America. Johnson Books, Boulder, CO.

Johnson, W.E., And S.J. O’Brien. 1997. Phylogenetic reconstruction of the Felidae using 16S rRNA and NADH-5 mitochondrial genes. Journal of Molecular Evolution 44:S98-S116.

Kaufman, J.H. 1987. Ringtail and coati. Pages 501-507 in M. Novak, J.A. Baker, M.E. Obbard, and B. Malloch, editors, Wild furbearer management and conservation in North America. Ministry of Natural Resources, Ontario, Canada.

Kenward, R.E., S.S. Wall, A.B. South, and N.M. Casey. 2008. Ranges 8: for the analysis of tracking and location data [online manual]. Anatrack, Ltd., Wareham, United Kingdom. Available from: http://www.ana track.com

KorTlucke, S.M. 1984. Variation in Bassariscus (Mammalia: Procyonidae). Doctoral dissertation, University of Kansas, Lawrence, KS.

LACY, M.K. 1983. Home range size, intraspecific spacing, and habitat preference of ringtails (Bassariscus astutus) in a riparian forest in California. Master's thesis, California State University, Sacramento, CA.

Lancia, R.A., W.L. Kendall, K.H. Polluck, and J.D. Nichols. 2005. Estimating the number of animals in wildlife populations. Pages 106-153 in C.E. Braun, editor, Techniques for Wildlife Investigations and Management. The Wildlife Society, Bethesda, MD.

Morales, G.C. 2006. Sobre el ámbito hogareño y los hábitos alimentarios de un carnívoro en un ambiente suburbano. El cacomixtle (Bassariscus astutus) en la reserva ecológica "El Pedregal de San Ángel." Tesis de maestría, Universidad Nacional Autónoma de México, Ciudad Universitaria, México, D.F. 
Müller, K., R. Klein, E. Miltner, and P. Wiegand. 2007. Improved STR typing of telogen hair root and hair shaft DNA. Electrophoresis 28:2835-2842.

Nams, V.O. 2000. Locate II. User's guide. Pacer Computer Software, Tatamagouche, Nova Scotia, Canada.

New Mexico Department of Game and Fish. 2011. New Mexico Big Game and Trapper Rules \& Information. New Mexico Department of Game and Fish, Santa Fe, NM.

Pollock, K.H., S.R. Winterstein, C.M. Bunck, And P.D. CuRTis. 1989. Survival analysis in telemetry studies: the staggered entry design. Journal of Wildlife Management 53:7-15.

RiCHARDS, R.E. 1976. The distribution, water balance and vocalization of the ringtail, (Bassariscus astutus). Doctoral dissertation, University of Northern Colorado, Greeley, CO.

Sato, I., S. Nakaki, K. Murata, H. Takeshita, and T. MuKAI. 2010. Forensic hair analysis to identify animal species on a case of pet animal abuse. International Journal of Legal Medicine 24:249-256.

SEVILLETA LTER. 2012. Sevilleta LTER. University of New Mexico; [accessed 24 November 2010]. Available from: http://sev.lternet.edu/data/climdb/search monthly.php

TAYLOR, W.P. 1954. Food habits and notes on life history of the ring-tailed cat in Texas. Journal of Mammalogy 35:55-63.

Texas Parks And Wildlife. 2009. Fur-Bearing Animal Regulations. Texas Parks and Wildlife, Austin, TX [cited 31 January 2012]. Available from: http://www. tpwd.state.tx.us/publications/pwdpubs/media/pwd_b r_w7000_0065.pdf

ToweILL, D.E. 1976. Movements of ringtails in Texas' Edwards Plateau region. Master's thesis, Texas A\&M University, College Station, TX.

Toweill, D.E., And J.G. TeEr. 1980. Home range and den habits of Texas ringtails (Bassariscus astutus flavus). Pages 1103-1120 in J.A. Chapman and D. Pursley, editors, Proceedings of the Worldwide Furbearer Conference. Frostburg, MD, 3-11 August 1980. R.R. Donnelley \& Sons, Falls Church, VA

TrAPP, G.R. 1973. Comparative behavioral ecology of two southwest Utah carnivores: Bassariscus astutus and Urocyon cinereoargenteus. Doctoral dissertation, University of Wisconsin, Madison, WI.

[UNSO] United States Naval Observatory, Astronomical Applications Department. 2010. U.S. Naval Observatory, Washington, DC. Available from: http:// aa.usno.navy.mil/data/.

White, G.C., And R.A. GarkotT. 1990. Analysis of wildlife radio-tracking data. Academic Press, San Diego, CA.

WooD, J.E. 1954. Food habits of furbearers of the upland Post Oak region in Texas. Journal of Mammalogy 35:406-415.

WyatT, D.T. 1993. Home range size, habitat use, and food habits of ringtails (Bassariscus astutus) in a Central Valley riparian forest, Sutter Co., California. Master's thesis, California State University, Sacramento, CA.

YARCHIN, J.C. 1988. Home range utilization, activity patterns, resting site characteristics, and food habits of ringtails (Bassariscus astutus) in a riparian area of central Arizona. Master's thesis, Northern Arizona University, Flagstaff, AZ.

1994. Home range use by ringtails in a southwestern riparian area. Pages 156-164 in P.R. Krausman and N.S. Smith, editors, Proceedings of the Managing Wildlife in the Southwest Symposium, October, 1990. Southwest Section of The Wildlife Society, Tucson, AZ.

Received 5 September 2011 Accepted 6 July 2012 